\title{
Place of Women in Sri Lankan Society: Measures for Their Empowerment for Development and Good Governance
}

\section{H.M.A. Herath}

University of Sri Jayewardenepura, Sri Lanka

\begin{abstract}
Despite far-reaching economic, social and political developments in Sri Lanka over the last century or so, Sri Lankan women continue to occupy a subordinate status. While women are not subjected to extreme forms of oppression, many adverse structures and forces, such as the patriarchal social structure, woman's role in the family, traditional values, rituals and myths, the division of labour and unequal pay, and women's lack of participation in politics contribute to the continuing subordination of Sri Lankan women. In this context, this article seeks to address the socio-economic, cultural and political processes that shape the status and the progress of women in Sri Lanka. It emphasizes the policy makers to ensure that Sri Lankan women are empowered to participate in development. For this to happen, the article, however, argues that an attitudinal change and a paradigm shift in the minds of policy makers and the society at large must be accomplished.
\end{abstract}

\section{Keywords}

Empowerment, Sri Lanka, Subordination, Women

\section{Introduction}

Sri Lanka has gained recognition throughout the world, mainly for three significant features: firstly, for the growth and export of fine Ceylon tea, secondly, for electing the world's first woman prime minister, Ms. Sirimavo Bandaranaike, and thirdly, for the protracted civil conflict of nearly 25 years, which ended at least on the military sphere recently. It is the second feature

\section{Corresponding Author:}

H.M.A. Herath, Department of Public Administration, University of Sri Jayewardenepura, Nugegoda, Sri Lanka. E-mail: hma_herath@yahoo.com 
here that has a significant bearing on the theme of this paper. Regarding the phenomenon of a woman holding the highest political office in the country, Kumari Jayawardena stated:

Sri Lanka attracted a great deal of attention in 1960 when Sirimavo Bandaranaike became the world's first woman prime minister. This was widely interpreted, in Sri Lanka and outside, as an indicator of the role and position of women in Sri Lankan society, a position of equality and independence. (1986, p.109)

But is this perception of 'equality and independence' an accurate reflection of the lives of the majority of Sri Lankan women? In comparison with women in other developing nations, Sri Lankan women do indeed appear to be significantly better off in terms of empowerment (e.g. see Asian Development Bank, 2008; United Nations Development Programme, 2014). Entering a public or private workplace, one would see a fairly large number of women, sometimes outnumbering men. Many Sri Lankans interpret this as an indicator of the status of women in Sri Lankan society, and some also argue that women have equal status and independence in the society. However, the hidden reality is that, on the whole, women hold minor positions with low status and low pay in the workforce (Jayaweera, et al., 2007). Thus, the greater participation of women does not necessarily imply they are well off, or that they are better off than their peers in other developing countries. Instead they are often subject to many discriminatory processes and forces in the work milieu, such as sexual harassments and glass ceiling (Wickramasinghe \& Jayatilaka, 2006; Hewamanne, 2008; Jayawardena, 2014).

After six decades of independence, majority of the Sri Lankan population still experience relatively low socio-economic standards and political engagement. Good governance could have an important and positive impact on all aspects of development in Sri Lanka, but despite democratization, the importance of women's potential contribution to development and the political process is not recognized (Lindberg, 2004). Further, to the development of the country, it is vital to increase the contribution of women. However, there exists a significant obstacle to women's full and equal participation in the economic and political process: the centuries-old mind-set still promotes male as the dominant player. Thus, despite the fact that both men and women received the universal franchise in 1931, that the literacy rate is above $90 \%$, and that education has long been prioritized for males and females, women in Sri Lanka, especially the rural women, are treated as second-class citizens in the socio-economic and political spheres.

In this context, the prime objective of this paper is to address the socio-economic, cultural and political processes that affect the status and progress of women, as well as to point out the importance of the empowerment of women to enable their full participation in the development process and, ultimately, their contribution to good governance.

In comparison with women in other developing countries, Sri Lankan women appear to be greatly privileged. Indeed, many (men, in particular) are of the view that women are treated very well in the climate of the predominantly Sinhalese-Buddhist culture, where the mother figure is revered as a goddess at home and mothers are highly respected in the society as a whole (Obesekara, 1990). Furthermore, the argument goes, due to the respect accorded to womenfolk, a great many of them have attained the status of doctors, engineers, lawyers, administrative officers, diplomats, university lecturers and other such high positions in society; therefore, no subordination of women is found in Sri Lankan society. 
Unlike in other developing countries, Sri Lanka women flourish in many professions, owing in large part to access to comparatively better educational facilities (Goonesekere, 2000). Nevertheless, women are not well represented in planning or at decision- or policymaking levels in either the private or public sectors (Amarasuriya, 1995). In this context Jayaweera and others discussing the participation of women in decision-making bodies in the public domain, notes:

In the private sector, in the Directorates of 23 large establishments listed under 20 different areas, only $6.1 \%$ were women. Also, noteworthy is the fact that $68.2 \%$ of private large establishments had no women in their Board of Directors. (2008, p.162)

In another study, Yoga Rasanayagam, looking at the role of women as both agents for and beneficiaries of rural housing programmes in Sri Lanka (the model village programme and the Village Reawakening Programme under the Million Houses Programme initiated by the government), makes a not-surprising finding:

Women's role in Sri Lanka as planners and decision makers in housing programmes remains neglected and unfulfilled. In the designing of houses for these programmes Sri Lankan women have not participated as members of planning boards or planners. (1993, p. 149)

The examples above show that, despite the fact that fifty years ago a woman occupied the seat of the Prime Minister of Sri Lanka, the progress and achievements of the great majority of women up to the present day have not yet extended to the level of governance, where their active and equal participation is vital to development. It might be instructive to briefly examine the apparent contradiction here.

When Sri Lanka elected the world's first woman prime minister in 1960 and later, in 1995, the first woman executive president, many argued that these achievements were possible, because Sri Lankan women already enjoyed high social status, equality and independence, and because the society provided a healthy atmosphere for women to prosper through modernization and especially through free education. It was further argued that the political success of these two women would further improve the opportunities for women to attain positions of politics in Sri Lankan society. In fact, the reality was, and remains, very different. The election of Ms. Sirimavo Bandaranaike as Sri Lanka's prime minister in 1960 and her daughter, Ms. Chandrika Bandaranaike Kumaratunga, as the executive president in 1995 were two exceptional and unique cases. As Kumari Jayawardena puts it:

The few women who have successfully contested and made a name for themselves in the political process have generally entered politics as the result of the death of a father or a husband, inheriting, as it were, the male's mantle of power as did Sirimavo Bandaranaike, who entered politics after the assassination of her husband who was prime minister at the time. (1986, p. 129)

Following the assassination of the Prime Minister S.W.R.D. Bandaranaike, an Oxford-educated and very popular politician from an aristocratic family, his wife, Sirimavo Bandaranaike, who hailed from the same aristocratic class, succeeded him in office. History, ironically, repeated itself thirty five years later when their daughter became the prime minister and then was elevated to the office of executive president, mainly because of her exceptional dynasty and 
the sympathy vote she attracted after the assassination of her husband, Vijaya Kumaranatunga, a film idol and highly popular politician.

It is clear that these two women reached the highest positions in government not because opportunities for equal participation in politics were widely available to all women, as some argued, but owing to the specific coincidence of wealth, privilege and sympathy, the latter in particular opening the way to their inheritance of the male mantle of power. So these two rare, exceptional cases do not reflect the reality of the majority of women in Sri Lanka - which is that their economic, social and political status in the society is subordinate to that of men.

Another unique historical event that has affected the position of women in Sri Lankan society in comparison to that of women in other third-world countries relates to how Sri Lanka gained its independence and the part the women's movement played in that process. Although during the independence or revivalist struggle women's, particularly Sinhala women's, identities were rearticulated, women's role in the independence struggle was rather evident (Jayawardena, 2000).

Sri Lanka gained independence from Britain in 1948 without much struggle and due to a series of successful negotiations. Women members of the elite class rendered a substantial service in that process, with the result that the right to education, universal franchise, equal treatment before the law and other such significant rights were granted to both sexes equally. In fact, universal franchise was granted to both sexes above 21 years of age in 1931, long before independence (Jayawardena, 1986). Thus, the process of the formation of Sri Lanka as an independent country was different from that of most other third-world countries, and the rights granted to women in that process were exceptional, a fact that has led to the misconception that the women of Sri Lanka enjoy equality in all aspects of socio-economic and political life. The reality - that traditional beliefs, attitudes and social practices have kept women in subordinate roles at all levels of the society-is explored in the following pages.

\section{The Patriarchal Social Structure}

A complex fabric of conventions, beliefs, values, attitudes and prejudices woven on the loom of traditions and historical experience winds through many levels of Sri Lankan society. Women brought up in traditional or orthodox family milieus, especially middle-class (see Hewamanne, 2008) believe that such sentiments are natural phenomena and are unable to see them as attributes of their socio-economic background. Referring to feudal, colonial capitalist formations in Sri Lanka, Hema Goonatilake highlights the barriers to women's emancipation and empowerment:

This is a struggle against accepted customs, values, attitudes and prejudices arising from various historical experiences. Women are taught to accept certain institutions as 'natural' while the man-made codes of behaviour provide the seeming rational. (1976, p.16)

Many women have defined their lower status as their destiny, because it is inscribed in their religious beliefs. Highlighting the vital importance of women's empowerment, Swarna Jayaweera argues:

The education process should also be consciously used to empower women to challenge obscurantist practices and rituals that perpetuate the subordination of women in the family through marriage practices and acceptance of patriarchy in household decision making. (1995, p.21) 
One such patriarchal practice that disadvantages women economically is the distribution of the family estate. Since the era of kings, estates have been inherited along the patriarchal kinship line. Daughters receive a dowry while sons enjoy the family estate, although the Kandyan Law clearly accepts women's property right (Ponnambalam, 1982). Thus, despite several changes have been made in Sri Lankan property law, the normal practice remains patriarchal, with the result that it is difficult for a woman to obtain loans from formal lending institutions, such as banks because even at present the land and other assets are mainly in the husband's name. Even the Thesavalamai Law on transfer of the estate (confined to the Tamil community in Jaffna district), which grants women some property rights, discriminates against women economically. According to Savitri Goonesekere,

Tamil women governed by Thesawalamai cannot transact business without the consent of their husbands. Thus, some banks in Sri Lanka have been given legal advice to the effect that they should obtain the husband's consent in regard to commercial transaction with women constituents. (1986, p. 22)

The orthodox society remains patriarchal to the present day, and the affluent still transfer property along patriarchal lines (It is a separate issue that a considerable propotion of the population has no tangible assets to transfer).

\section{The Role of Women in the Family}

In a patriarchal setting, important family decisions are made by males. Wives seldom enjoy decision making power. After the marriage, almost all brides are taken into bridegroom's home, which, in villages, may be the house of the bride's father- and mother-in-law. Nevertheless, in the Kandyan region and under binna marriage of the Kandyan Law there was a tradition that the groom settled down in the bride's house (Ponnambalam, 1982). Depending on the situation, the newly married couple may stay there for some years, and sometimes the husband builds his own house close to his parents' house. In the home, the wife is responsible for most household activities, including cooking, washing, child care, care of the elderly, and hospitality for relatives, neighbours and visitors, although this is now changing, especially in urban middle-class family settings.

In the past, even in urban settings, most women did not go out to work. In the present context, the majority of women is employed, and is expected to handle all the household work in addition to the busy routine of their daily jobs. As a result, women in Sri Lanka, both rural and urban, have to bear the burden of two jobs-in the workplace and the home. Once they return home from their work, whether it be in the paddy field, the tea estate, or an office in the government or the private sector, women are responsible for domestic chores, and even helping children with their studies, Yet, in urban middle-class family settings, there is a recent tendency that men also take the responsibility of the domestic chores. Further, some urban families employ domestic servants, but it is the wife who still must shoulder the responsibility for household affairs, although the domestic work undertaken by women remain socially under-valued. As Swarna Jayaweera highlights, for example:

Household work is perceived to be exclusively 'women's work' by both men and many women. Hence, studies have shown that women have a daily work load of 14 hours coping with their economic, social and domestic roles, while men work 9 hours a day. (1995, p. 20) 
Even in this underprivileged context, many women consider it a point of pride to be depended upon to carry out almost all household work without the husband attending to even a minor job, such as making a cup of tea in her absence. Such an attitude shows the dedication and willingness of wives, who have grown up with traditional patriarchal values and beliefs about the woman's role in the family, to serve their husbands happily while carrying the burden of the domestic workload (Jayawardena, 1994).

This dedication and commitment by women makes their role in rural family settings rougher and tougher since they are required to take domestic responsibilities, such as collecting water and firewood (Wickramasinghe, 1993). Women in rural settings assume that they must shoulder the burden of household activities, leaving the husband to deal with the larger society and the community. Her place is in the home. At meal times, especially in rural settings the husband is served first, and then the boys, starting with the eldest, followed by the daughters. This is because of the belief that men are involved in heavy work, not light work like women. The mother is the last to eat.

Another aspect of family life that entrenches a young girl's perception of herself as inferior to males is the socialization process that begins within the family circle. Women in many Asian countries are socialized as part of an extended family guided by traditional values and customs. While a boy enjoys a care-free upbringing, a girl is carefully attended, and a mature girl is always shielded from interaction with the society around her and may miss many opportunities. As a result of this kind of protective of upbringing, girls grow up with little exposure to or knowledge of the broader society. Thus, rural girls in particular may be cruelly exploited when they travel to urban centres looking for jobs and other better opportunities. While conducting field research in Sri Lanka, Caitrin Lynch interviewed a father who explained the vulnerability of girls and the need for their protection in this way:

The reason is, she is a girl. She does not understand very much about the troublesome state of things in our country. When she goes, men talk to her for love and might even harm this child by taking her... This is a girl not a boy, right? There must be protection for girls, right?... If it is a boy it is okay. (2007, pp.159-160)

Obedience on the part of children towards their parents is considered a core virtue. Parents take immense care to raise virtuous daughters. The traditional controlled upbringing of daughters has created a vacuum in the development of girls' social role, to the extent that they lack independence in decision making and experience uncertainty in the face of challenges. In most families, for example, the oldest daughter, even in adulthood, lacks the decision-making power of her youngest brother.

The foregoing discussion illustrates how certain aspects of the patriarchal system perpetuate the subordinate status and the expectations of women in Sri Lankan society. Yet, addressing the patriarchal structure is only a small step toward the empowerment of women socially and economically and enabling their full participation at all levels of the political process, as Diane Elson and Ruth Pearson argue:

Though ideology plays a role, we would argue that the subordination of women as a gender cannot be understood simply as matter of 'patriarchal attitudes'. Rather it is a material process which goes on not just in our heads, but in our practices. In claiming that it is a material process we do not intend to reduce it to an economic process, to be analyzed only in terms of labour, but rather to emphasise that it cannot 
be changed simply through propaganda for more 'enlightened' views, but requires practical changes in daily living. (1991, p.25)

This is the real issue. Women are heavily involved in non-wage work, such as agricultural farming and domestic duties, which are socially under-valued and considered as less productive. As evidence shows, women are low in the hierarchy of authority. Their subordination and the restrictions that prevent them from participating in decision making are well documented. There need to be positive changes to address these practical problems that women confront in the contemporary socio-organizational milieus, and to enable them to develop and realize their aspirations. Girls and women need to be afforded, in the same way as boys and men are, opportunities for developing their full potential and to integrate into society and thereby contribute to national development.

\section{Myths, Beliefs and Attitudes}

Major impediments to women's development are the paradigms engendered by myths, blind beliefs and patriarchal concepts that hinder their independence and dignity. Many examples could be cited from the folklore in this regard: 'Women are born with weak intelligence'; 'The brain power of women is a spoon's length long'; 'Woman is the weaker sex'; 'Woman is ever changing and therefore not trustworthy'. These sayings imply that women are not only undervalued, but they deserve to be confined to an inferior position in the social hierarchy. This was the case not only in Sri Lanka, but generally throughout the developing world in the 1970s, as pointed out in the Cover Story of Economic Review:

In spite of legal and political equality, in theory true equality for masses of women is still a myth. This situation with minor variations is more or less the same in most Asian Countries such as India, Indonesia, Sri Lanka, Burma, Laos, Malaysia and the Philippines where the hold of tradition is still quite strong and where customs, rituals, beliefs and social norms continue to perpetuate the dictum of the male's superiority. (1976, p. 3)

Even today, in Sri Lanka the situation has not changed very much. Despite ongoing interest in the status of women, and the various development projects initiated by international organizations and NGOs that have focused on women's issues and the empowerment of women in Sri Lanka for nearly four decades or so, women remain disadvantaged, marginalized and subordinate in many respects.

The present understanding of many educated Sri Lankans is that these fallacies and negative ideas about women are found only in the village districts, but this is not the case. These persistent underlying ideas permeate the culture, and the discouragement they cause can be powerful, eroding the self-confidence of women. In a less subtle way, uneducated and illiterate people may make decisions based on these myths, since they have hardly exposed to egalitarian values and gender dynamics in contemporary society.

Even today, in many families the birth of a girl is not celebrated in the same way as that of a boy, although this is now changing in urban family settings. While the dowry system may influence such a reaction, many believe that to be born a girl is the result of sin committed in a previous birth. Therefore, the common religious belief is that one must cultivate more and more merits during this life to earn the reward of rebirth as a male in the next. 
During the course of their upbringing, rural girls are often denied opportunities to make decisions about their life. Such a child, born equal but raised in a confined environment, may be considered simple and 'backward,' not because she is retarded, or psychologically weak, or physically deformed, but because she has never been given the chance to develop her abilities. A girl brought up in a family holding traditional values will be taught to be polite, innocent, bashful and 'feminine' (Jayawardena, 1994; De Alwis, 2002; Miller \& Carbone-Lopez, 2013). Of course some of these qualities may be virtuous for both sexes. But if a woman moves in the society in a dignified manner, forms arguments in a rational way and acts in a sociable way, she is looked down upon for exhibiting qualities that are deemed masculine traits.

Some rural women do attempt and struggle to overcome economic barriers and move up in the society, despite the social and cultural obstacles they must confront, not the least of which may well be the reaction of their own husband. Casinader and others recount a case where a woman, Mallika, was endeavouring to set up a small business:

What is significant in this case study is that Mallika's husband is not positively oriented to helping her even in the purchasing and selling of cashew nuts, let alone the manual processing of the nuts by decorticating the outer skin. The case study shows how ... a husband has [difficulty facing] up to situation in which he is not the breadwinner, a role socially and culturally expected of the men. (1987, pp. 316-317)

In this context of a woman's place in the social order, a widow too is expected to be very meek and mild, calmly bearing her worries and agonies. It is a cruel aspect of their diminished status as single women that widows are considered unsuccessful due to their own folly. Yet, at the same time women are compelled to be head of the household. Nevertheless, most of these widows are unemployed. In some female-headed households, the husband has gone abroad to earn a living. In other cases the husband is a drunkard. Addiction to illicit liquor is a growing and serious problem among poor people in both urban and rural areas in Sri Lanka. As a result, women have to bear the burden, not only of a drunken husband, but of providing for the family (Herath, 2008, p.324).

\section{The Impact of the Dowry System}

The origins of the dowry system in Sri Lanka lie in the distant past. In orthodox families, dowry was originally given to preserve the independence of the bride. Parents also took this opportunity to express their affection for their daughter by offering the token of dowry. Over time, the dowry system was established as a required element in traditional weddings. Referring to the still prevailing dowry system in Sri Lanka, Caitrin Lynch illustrates the importance of the dowry as part of the marriage process among poor rural female workers in the garment industry:

It was common for these women to enter into arranged marriages, which usually required dowries, as indeed did some 'love marriages'... the larger the dowry, the better the marriage match. (2007, p.174)

Lynch describes the efforts of one such worker who was attempting to save money for herself, but had to use it for her dowry:

She saved some money in a bank account, but by the time she married she had spent it all on items for herself and for her dowry. Her brothers also, contributed to her dowry. (2007, p. 51) 
Further, in the Jaffna peninsula, where Tamils predominantly live, father-in-law asks for an extra bride-price in addition to the dowry when the bridegroom has a sister. This brideprice is donated back to the bridegroom of the sister on her wedding day. Regardless of the economic and social position of the bride, even if she is a doctor, for instance, the dowry remains a necessity. An unfortunate result of the dowry requirement is that poor parents and women who are not able to fund a dowry sufficient for a suitable marriage might be forced to delay marriage indefinitely.

\section{Women's Participation in Politics and Trade Union Activities}

The level of participation of women in party politics has been highly unsatisfactory. Although universal franchise was granted in 1931 to both sexes, the women MPs in the overall composition of Parliament, the Local Authorities of Provincial Councils or the Pradeshiya Sabahs (Local Councils) of the country remains insignificant. In fact, as statistics show “... women constitute only 5.8\% MPs in Parliament while the female male ratio in Parliament is a dismal 0.056" (Wickramasinghe \& Kodikara, 2012, p. 789). Women representation in cabinet portfolios is no different, if not worst. Throughout the history of parliamentary democracy in Sri Lanka it is a common understanding that women MPs are offered insignificant, not key, portfolios. Indeed despite more than 68 years of universal adult franchise, the equality of the sexes in law, the modernization process and more than half a century of free education for both sexes, female representation in parliament and the two lower political institutions, namely the Provincial Councils and Pradeshiya Sabhas, does not indicate any positive trend towards increasing.

Even in the universities, where student enthusiasm for politics is outstanding, a familiar pattern is seen in the student political structures. Although the majority of undergraduates are female, the leadership of all the student councils is dominated by boys, with girls' membership usually confined to the executive committees.

Women's participation in trade union activities is similar to their engagement in politics. In the unions, women's participation is confined to the membership and they are not found among the office holders. For example, in professional jobs, such as teachers, nurses and doctors women representation is above 60\% (see Department of Census and Statistics, 2013), but all the key office holders of these trade unions are male professionals. When it comes to other areas and industries, such as apparel industry and planation sector, in which women are the majority, office holders of the trade unions are men (Samarasinghe, 1993; Gunawardana \& Biyanwila, 2008).

\section{Education}

The standard of education in Sri Lanka, even before independence, has been exemplary. Free education was granted universally to males and females shortly after independence. Even text books have been provided free of charge since the 1980s. Gender equality in participation in the formal education system has been the case for some time, though since 2000 the number of females has surpassed the number of males. In 1950, the number of girls participating in the formal education system was $18.7 \%$; by 1978 , the figure had risen to $37.7 \%$; and in the year 2000, girls' participation reached $51 \%$. This trend has been prevalent as well in the secondary and post-secondary education spheres (see Ministry of Education, 2008). 
As a result of this trend, women have gained much ground in the ranks of highly paid professions in the country. In the medical, management and banking sectors, women are well represented in comparison to men. In the universities today, female undergraduates excel in the disciplines of humanities and social sciences, law, management studies, and medicine and science. In fact female students consist of $60 \%$ of undergraduate population in Sri Lankan university system (University Grants Commission of Sri Lanka, 2013). However, female participation remains low in the areas of technical, technological and vocational training for the trades.

On the other hand, teaching, weaving, nursing, picking, labelling, assembling, sewing work in the garment industry, agricultural activities, tea packing, rubber-tapping and coir production work in the plantation sector are the most popular jobs among women. This is because, as Malathi de Alwis argues, the jobs considered best for women in Sri Lanka represent 'a continuation of domestic chores in the Public domain' (1995, p. 142) The political scientist Jean Grossholtz also notes that women in the 1980s preferred occupations, such as school teacher, nurse, typist, stenographer and retail sales clerk (1984, p.125). She argues that these jobs were considered appropriately female since they relied on skills developed by doing housework (taking care of children, nurturing, and waiting on others) and were sought after because the flexible hours could be combined with household duties. This is particularly the case with teaching jobs, where most schools begin at 7.30 a.m. and finish at 1.30 p.m., and provide a month-long vacation at the end of term. Such flexibility enables women teachers to attend to all household matters, including child care-a distinct advantage, incidentally, in finding a marriage partner.

Other professions are not so adaptable to the domestic demands placed on women, and therefore are not so readily embraced. As Nimala Amarasuriya points it,

A number of factors, both cultural and socio-economic limit women's opportunities in the $\mathrm{S}$ and $\mathrm{T}$ [science and technology] professions. For example, traditional cultural values and child-bearing and nurturing responsibilities lead many qualified women science graduates to seek teaching or desk jobs rather than go into the field. (1995, p. 27)

\section{The Division of Labour and Unequal Pay for Equal Work}

Sri Lanka is still considered to be an agricultural country. In the paddy fields, the division of labour is highly prevalent and well established. Traditionally, ploughing and tilling is considered a male job; re-planting, seeding, weeding, and preparing and bringing meals to the male partner are considered female jobs. In the plantation sector, tea-picking, rubber-tapping, and coconut coir mill labour are traditionally confined to female workers.

The division of labour is particularly well-defined in the domestic setting, as discussed earlier, where the economic contribution of women is largely ignored. Here, 'women's work' in the form of cooking, collecting fire-wood, gardening and horticulture, animal husbandry, child-care, shopping, sewing for the household needs, supplying of drinking water, ironing clothes, washing etc., is not considered as having any monetary value and therefore is not represented in the national income statistics. Women are also highly present in unskilled labour activities, such as cleaning, collecting garbage, sweeping, sanitary labour, and in jobs such as, traffic wardens and security guards, where very meagre wages are paid.

In the informal sector in Sri Lanka, in both the urban and rural environments, women have long been subject to discrimination in wages and salary. In the rural sector, agrarian female 
workers receive approximately half the wage paid to male co-workers for the same labour. For example, in the small-holder tea sector, a female weeder is paid less than the wage of a male weeder. In the urban sector, a female garbage collector or sanitary labourer is also given relatively lower salary than their male counterpart. Female domestic servants, in particular, have been harshly exploited by their employers, as Kumari Jayawardena points out:

There are no laws regarding wages, hours of work and conditions for domestic servants, with the result that women and girls in domestic service are often grossly underpaid and receive much lower wages than men servants although performing as arduous work. Moreover, it even happens that child servants are sometimes not paid at all. (1976, p. 14)

This situation persists to the present day. Female domestic servants may have to work 15 to18 hours per day for meagre pay. However, the male domestic servant earns somewhat better pay for what are often relatively easier tasks. So even at present, the issue of gender pay gap remains visible in many sectors of the country (see Jayaweera et al., 2007).

\section{Conclusion}

In terms of their standard of living and social status, many educated Sri Lankan women enjoy a moderate level as far as participation in the socio-economic and cultural spheres is concerned. In this regard, the experience of Sinhalese, Tamil and Muslim women is more or less the same (except for Indian Tamil workers in the plantation sector who are still subject to a quasi-feudal patriarchal socio-organizational structure). Further, women's representation in some of the highly paid professions, such as doctors and university lecturers is above or equal to that of males.

However, this encouraging picture of economic success does not depict a cross section of the wide spectrum of women's socio-economic experiences in Sri Lanka. In many areas, women lack opportunities for training and advancement, and remain trapped in less productive or socially under-valued employment, and condemned to poverty. The subordination of such women in Sri Lanka is closely related to the lack of opportunities and the sexual division of labour.

It is precisely for this reason that policy makers need to intervene to open space for women in the policy-making and implementation sections of the country's various governing bodies, from local councils to trade unions to government ministries. Even at present, both rural and urban women hold the lowest level positions in their organizations in the public and private sectors, and this simply perpetuates their powerlessness and vulnerability.

In this context, it is the duty of those in power to enable Sri Lankan women to contribute to the effort of development and good governance in a more effective and powerful manner. Both sexes must come together in examining the root causes of women's subordination and in seeking empirical solutions. For such an endeavour to progress, an attitudinal change and a paradigm shift in the minds of policy makers and in the society at large must be accomplished through education and changes in social practices. In this monumental effort, far-sighted policy makers must play an active and pragmatic role. There is much evidence to show that women are low in the hierarchy of authority, and that this restricts their ability to participate in decision making and policy making at all levels of society. As a result, women have very little power in political matters. The prevailing situation is such that policies that affect the 
progress and the social conditions of women are being made without their participation, that is, in the absence of those who should have the real say in matters which directly affect them.

What is needed, then, is the direct involvement and direct representation of women in planning, policy making and in top-level decision-making bodies. Once the need for development to be more equitable and people-oriented is recognized as a vital concern, then policy makers will be ready to acknowledge the importance of women's role in development and good governance and to take the necessary steps towards their empowerment.

\section{References}

Amarasuriya, N. R. (1995). Women and Technology. Economic Review, Colombo: People's Bank Publication, 20(12), 26-30.

Asian Development Bank. (2008). Country Gender Assessment Sri Lanka. Manila: Author.

Casinader, R., Fernando, S., \& Gamage, K. (1987). Women's Issues and Men's Roles: Sri Lankan village experience. In J.H. Momsen and J. Townsend (Eds.), Geography of Gender in the Third World. (pp. 309-322). Albany: State University of New York Press.

Cover Story. (1976). Women and Development. Economic Review, Colombo: People's Bank Publication. 2(6), 3-5.

De Alwis, M. (1995). Gender, Politics and the 'Respectable Lady'. In P. Jeganathan and Q. Ismail (Eds.), Unmaking the Nation: The politics of identity and history in modern Sri Lanka. Colombo: Social Scientists' Association.

De Alwis, M. (2002). The Changing Role of Women in Sri Lankan Society. Social Research, 69(3), 675-691.

Department of Census and Statistics. (2013). Sri Lanka Labour Force Survey Annual Report - 2013. Retrieved from http://www.statistics.gov.lk/samplesurvey/LFS_Annual\%20 Report_2013.pdf

Elson, D. \& Pearson, R. (1991). The Subordination of Women and the Internationalization of Factory Production. In K. Young, C. Wolkowitz and R. McCullagh (Eds.), Of Marriage and the Market: women subordination internationally and its lessons. (pp. 18-40). London: Routledge.

Goonesekere, S. W. E. (1986). The Impact of the UN Decade for Women on the Legal Status of Sri Lankan Women. Economic Review, 11(10), 20-24. Colombo: People's Bank Publication.

Goonesekere, S. W. E. (2000). Legal Education in Independent Sri Lanka. In S. Thilakaratna and M. P. M. Gunasena (Eds.), University Education since Independence. (pp. 86 110). Colombo: University Grant Commission.

Grossholtz, J. (1984). Forging Capitalist Patriarchy: The economic and social transformation of feudal Sri Lanka and its impact on women. Durham: Duke University Press.

Goonatilake, H. (1976). Social and Political Participation: Tradition, prejudice, myth, reality. Economic Review, 2(6), 16-17.Colombo: People's Bank Publication.

Gunawardana, S. \& Biyanwila, J. (2008). Trade Unions in Sri Lanka. In J. Benson and Y. Zhu (Eds.), Trade Unions in Asia: An economic and sociological analysis. (pp. 177-198). New York: Routledge.

Herath, H. M. A. (2008). Grassroot Institutions for Regional Development: Sri Lankan experience. Vidyodaya Journal of Humanities and Social Science, 2, 305-334. 
Hewamanne, S. (2008). Stitching Identities in a Free Trade Zone: Gender and politics in Sri Lanka. Philadelphia: University of Pennsylvania Press.

Jayawardena, D. (2014). HRM as a "Web of Texts": (Re)articulating the identity of HRM in Sri Lanka's localized global apparel industry. Organization Management Journal, 11(4), 289-298.

Jayawardena, K. (1976). Women and Employment. Economic Review, Colombo: People's Bank Publication, 2(6), 14-15.

Jayawardena, K. (1986). Feminism and Nationalism in the Third World. London and New Jersey: Zed Books Ltd.

Jayawardena, K. (1994). Religious and Cultural Identity and Construction of Sinhala Buddhist Womanhood, Nivedini, 1(1), 111-139.

Jayawardena, K. (2000). Nobodies to Somebodies: The rise of the colonial bourgeoisie in Sri Lanka. Colombo: Social Scientists Association.

Jayaweera, S. (1995).Women Education and Development. Economic Review, Colombo: People's Bank Publication, 20(12), 15-21.

Jayaweera, S., Gunawardena, C., \& Edirisinghe, I. (2008). Beyond the Glass Ceiling: Participation in decision making in the public domain. Colombo: Centre for Women's Research (CENWOR).

Jayaweera, S., Wijemanne, H., Wanasundera, L., \& Vitarana, K.M. (2007). Gender Dimensions of the Millennium Development Goals in Sri Lanka. Colombo: Centre for Women's Research (CENWOR).

Lindberg, S. I. (2004). Women's Empowerment and Democratization: The effects of electoral systems, participation, and experience in Africa. Studies in Comparative International Development, 39(1), 28-53.

Lynch, C. (2007). Juki Girls, Good Girls: Gender and cultural politics in Sri Lanka's global garment industry. New York: Cornell University Press.

Miller, J. \& Carbone-Lopez, K. (2013). Gendered Carceral Regimes in Sri Lanka: Colonial laws, postcolonial practices, and the social control of sex workers, Signs, Journal of Women in Culture and Society, 39(1), 79-103.

Ministry of Education (2008). School Census - 2008 Preliminary Report. Colombo: Author. Retrieved from http://www.statistics.gov.lk/education/PreliminaryReport-2008.pdf

Obesekara, G. (1990). The Work of Culture, Chicago: Chicago University Press.

Ponnambalam, S. (1982). Law and the Marriage Relationship in Sri Lanka, Stamford Lake Publication: Colombo.

Rasanayagam, Y. (1993). Women as Agents and Beneficiaries of Rural Housing Programmes in Sri Lanka. In J. H. Momsen and V. Kinnaird (Eds.), Different Places, Different Voices: Gender and development in Africa, Asia, and Latin America. (pp. 146-158). London: Routledge.

Samarasinghe, V. (1993). Access of Female Plantation Workers in Sri Lanka to Basic Needs Provision. In J. H. Momsen and V. Kinnaird (Eds.), Different Places, Different Voices: Gender and development in Africa, Asia, and Latin America London: Routledge, 131145

United Nations Development Programme. (2014). Human Development Report. Retrieved from http://hdr.undp.org/sites/default/files/hdr14-report-en-1.pdf 
University Grants Commission of Sri Lanka. (2013). Sri Lanka University Statistics 2013. Retrieved from http://www.ugc.ac.lk/en/component/content/article/1418-sri-lankauniversity-statistics-2013.html

Wickramasinghe, A. (1993). Women's Role in Rural Sri Lanka. In J. H. Momsen and V. Kinnaird (Eds.), Different Places, Different Voices- Gender and Development in Africa, Asia, and Latin America. (pp. 159-175). London: Routledge.

Wickramasinghe, M. \& Jayatilaka, W. (2006). Beyond Glass Ceilings and Brick WallsGender at the Workplace. Colombo: ILO.

Wickramasinghe, M. \& Kodikara, C. (2012). Representation in Politics: Women and gender in the Sri Lankan republic. Retrieved from http://republicat40.org/wp-content/ uploads/2013/01/Representation-in-Politics1.pdf 